\title{
Analysis of Long-Term Plan for Energy Supply System for Latvia that is $100 \%$ Based on the Use of Local Energy Resources
}

\author{
Jekaterina Porubova, Institute of Energy Systems and Environment, Riga Technical University, Gatis Bazbauers, \\ Institute of Energy Systems and Environment, Riga Technical University
}

\begin{abstract}
The prices of fossil energy resources are expected to rise substantially in the future, therefore fossil energy resources might not be a feasible energy source for Latvia in the long term. The establishment of a fully self-sufficient energy supply system will require a significant transformation of the existing energy supply and transport infrastructure. Early planning of such a system makes it possible to shape development of the existing energy system in order to achieve that goal of a fully selfsufficient energy supply system. The paper shows a potential solution to establish an energy and transport system solely based on the domestic primary resources by the year 2050 .
\end{abstract}

Keywords - energy supply system, energy security, flexible electric transport, renewable energy sources (RES).

\section{INTRODUCTION}

The prices of fossil energy resources are expected to increase considerably in the future due to the increased costs in extracting the more difficulty accessible resources and the fall of supply capacity which cannot meet demand. Therefore, fossil energy resources might not be available for Latvia in the long term either because of a physical shortage or an excessively high cost of those resources. Under these circumstances, Latvia will have to fully satisfy its energy needs with domestic energy resources. The establishment of an energy supply system that is based $100 \%$ on local energy resources is a complex task that will require a significant transformation of the existing infrastructure of energy supply and transportation, and the application of new solutions that integrate different energy sources for electricity, heat and transport energy supply. It is important to start early with the research and planning of such a system since that will make it possible to ensure that the development of the existing energy supply and transport systems achieve the goal of the fully selfsufficient energy system.

The main goal of the work was to understand: 1) whether it is possible to create an energy system, including transport, which is based $100 \%$ on domestic energy sources; 2) what could be the primary resource mix of that system; and 3) whether the currently estimated potential of supply of those resources is sufficient to fully cover the needs of this selfsufficient energy system.

In case of Latvia, the local energy resources are renewable energy sources, combustible waste and peat. Thus, the structure of a Latvian energy supply that covers the energy demand in all sectors of final energy consumption is developed based on the above mentioned energy sources, excluding peat. The time frame that is chosen for the study is the year 2050 which is a sufficiently long period in order to create an energy supply system which is independent of the currently applied energy technologies.

\section{METHOD APPLIED}

Analysis of the structure of the self-sufficient energy supply system is conducted by using the input/output deterministic energy system analysis model "EnergyPLAN" (version 8.0) which is developed and constantly improved upon at the Aalborg University in Denmark since 1999 [1]. This approach is selected because the goal of the study was to find out the possible source structure of the energy supply system and the characteristics based on the energy consumption forecasts. Today, there are more than 60 different types of software available for the simulation of energy supply systems in accordance with the aforementioned objectives. In cases when an energy system is developed by considering the use of the local energy sources of a country, some of the programs which can be used for analysis (in addition to "EnergyPLAN") are the following [2]:

- "INFORCE";

- "Mesap PlaNEt";

- "H2RES";

- "SimREN".

„EnergyPLAN" is a user-friendly program that was developed using "Delphi Pascal" [1]. The model can be used to simulate energy supply systems on the country level or regional scale by using data of the existing systems or future forecasts. Data on electricity, district heating demand, fuel consumption in sectors of final energy use, data on capacities and energy production of the energy sources, technical characteristics of energy storage technologies and flexible consumers, as well as economic and environmental information is supplied by the used and inputted to the model. Simulations with "EnergyPLAN" allow the determination of a resource mix, costs and environmental outcome for the specific solution in the corresponding energy supply system. The main advantage of the analysis model in comparison with some others is that „EnergyPLAN" makes calculations based on the hourly distribution of electricity, heat and transport demand, and supply of intermittent renewable sources throughout the year. The analysis of energy systems on an hourly basis is very important for those systems that have a large proportion of intermittent renewable energy sources in the supply mix since the production of energy from those 
sources has significant daily and seasonal variation, and yearly integrated energy values could be quite different those obtained through calculations which consider hourly variations.

„EnergyPLAN" was used to simulate a 100\% RES-based energy supply systems in Denmark, Ireland and for Mljet Island in Croatia, as well as for defining RES and cogeneration potential in Estonia, Germany, Poland, Spain, and the United Kingdom [2].

„EnergyPlan” operates based on data input/output principle and the main input data types are [3]:

- Energy consumption (heat, electricity, energy for transportation and cooling energy demand);

- Available RES;

- Installed capacity of power plants, cogeneration plants (CHP) boiler houses, heat pumps and energy storage technologies (e.g. electrolysers, compressed air and hydro pumping systems)

- Costs (including taxes);

- Regulation settings for calculations (e.g. balancing heat or heat and electricity demand, technical or market economic optimization) [3]; and

- Others.

The output data includes:

- Balance of energy;

- Amount of produced energy within one year (showed on an hourly basis in the results);

- Export/import of electrical energy;

- Fuel consumption;

- Total costs, including economic data of electricity exchange [3].

\section{RESULTS AND DISCUSSION}

About $70 \%$ of the primary energy sources used within the territory of Latvia in the year 2008 was imported [4]. The largest share of these sources was imported from Russia (electricity and natural gas import from Russia make up circa $32 \%$ of the import) and Russia is the only country that supplies natural gas to Latvia [4]. The Latvian energy system has a very high dependence on natural gas which constitutes about $28 \%$ share in the primary energy supply, and about $80 \%$ of the district heat in Latvia was produced by using natural gas in 2008 [4].

At the same time, during the year 2008 Latvia had a high share of hydropower (39\%) and cogeneration $(27 \%)$ in the production mix of electricity, and the share of wood fuel used in the boiler plants of district heating systems and sectors of final energy use were $15 \%$ and $22 \%$, respectively [4]. In addition, Latvia exports substantial amounts of wood fuel ( $8,5 \%$ of the final energy use in 2008 [4]) which could be used in domestic cogeneration plants and boiler houses. As will be shown by the study, biomass is the domestic resource among those with the greatest potential to form the foundation for a self-sufficient energy system. Statistics [4] and estimates show that about $50 \%$ of the final energy consumption is used for the supply of heating needs (by district heating and individual heat supply systems), about $13 \%$ is used for electricity and $36 \%$ for transportation needs and various mechanisms (the remaining
$2 \%$ is non-energy usage). The relatively high share of transport energy needs indicates that complete securing of this demand by domestic resources could be the main challenge in creating a self-sufficiency energy scenario.

Biomass and hydro energy are the most widely used renewable energy sources in Latvia today. However, it should be noted that, in electricity production, wind energy is currently used at a considerably larger extent than biomass, and the amount of electricity produced by biomass cogeneration plants is currently negligible. Most of the biomass resources are used for heat production in district heating systems and sectors of final energy use.

Table I shows summarized data on the potential of available local energy sources in Latvia. These sources were used to develop scenarios of the future energy supply system for Latvia which is $100 \%$ based on the domestic resources.

TABLE I

POTENTIAL OF LOCAL ENERGY SOURCE AVAILABILITY

\begin{tabular}{|l|l|}
\hline Type of energy source & $\begin{array}{l}\text { Installed capacity or potential } \\
\text { amount of primary energy per } \\
\text { year }\end{array}$ \\
\hline Biomass & $30 \mathrm{TWh}[5]$ \\
\hline Onshore wind power plants & $600 \mathrm{MW}_{\mathrm{e}}[6]\left(1,32 \mathrm{TWh}_{\mathrm{e}}\right)$ \\
\hline Offshore wind power plants & $1200 \mathrm{MW}_{\mathrm{e}}[6]\left(3 \mathrm{TWh}_{\mathrm{e}}\right)$ \\
\hline Biogas & $7 \mathrm{TWh}$ \\
\hline Waste & $1,8 \mathrm{TWh}$ \\
\hline Biofuel & $10,5 \mathrm{TWh}$ \\
\hline
\end{tabular}

The potential of biogas (Table I) is calculated by using the maximum value of the annual biogas potential supply volume in the range of the estimated figures for this potential found in the literature [7], i.e. 1200 million $\mathrm{m}^{3}$ and lower heating value of biogas 5,8 MWh/thous. $\mathrm{m}^{3}$. This may seem too optimistic of an estimate for the biogas energy potential currently but may as well be used in the studies with such a long-term perspective since technological development may turn it in reality. The potential of combustible waste energy (Table I) is estimated by using forecasts of the amount of combustible municipal waste in the year 2050 [8], i.e. 600 thous. tons per year, and lower heating value of the waste $3 \mathrm{MWh} / \mathrm{t}$, which is calculated by considering the individual shares of possible components in the waste. The amount of biofuel (Table I) includes the existing production volumes of bioethanol and biodiesel, which is 75 thous. tons per year [9], and this is a very conservative estimate, since the production volumes may increase in the future. The structure or energy mix of the future energy supply system modeled in the scenarios which are presented in this work was based on the potential of available sources. The main task was to create a plan of the energy system which would utilize local energy sources with maximum efficiency avoiding energy import.

The main assumptions used in the forecasts to obtain the energy consumption for the year 2050 are the following:

- average growth of annual gross national electricity consumption in Latvia is equal to $1 \%$ per year starting from 8,6 TWh/year (Table II) in the year 2020 (this electricity consumption figure is taken from another 
study [10] and is chosen as the initial value for making forecasts);

- $\quad$ average growth of the demand of mechanical energy for the needs of the transport sector is equal to $2 \%$ per year starting from 4,8 TWh/year (Table II) in the year 2020 which is chosen as the initial value [10].

When forecasting mechanical energy demand for transportation, it was assumed that the energy demand will increase at the same pace as economic activity, i.e. gross domestic product (GDP). Authors of this paper did not find a long-term forecast of GDP increase and the assumption was made that it will be $2 \%$ per annum on average.

Table II shows the actual energy consumption figures for the year 2008 [4], the energy consumption forecasts obtained from the study [10], and energy consumption forecasts for the year 2050 obtained in this study by employing the above assumptions, and used as an input into modeling.

TABLE II

COMPARISON OF ENERGY DEMAND IN 2050 WITH THE DEMANDS IN YEARS 2008 AND 2020

\begin{tabular}{|l|l|l|l|}
\hline Type of energy source & $\mathbf{2 0 0 8}$ & $\mathbf{2 0 2 0}$ & $\mathbf{2 0 5 0}$ \\
\hline $\begin{array}{l}\text { Electricity (gross national } \\
\text { electricity consumption), TWh/year }\end{array}$ & 7,8 & 8,6 & 12,0 \\
\hline $\begin{array}{l}\text { District heating (production), } \\
\text { TWh/year }\end{array}$ & 7,3 & 6,0 & 4,0 \\
\hline $\begin{array}{l}\text { Household sector (primary energy } \\
\text { consumption), TWh/year }\end{array}$ & 10,3 & 6,1 & 3,2 \\
\hline $\begin{array}{l}\text { Industry sector (primary energy } \\
\text { consumption; includes industry, } \\
\text { service, construction and } \\
\text { agriculture sectors), TWh/year }\end{array}$ & 11,5 & 12,2 & 8,5 \\
\hline $\begin{array}{l}\text { Mechanical energy for transport, } \\
\text { TWh/year }\end{array}$ & 3,8 & 4,8 & 8,8 \\
\hline
\end{tabular}

Forecasts of primary energy consumption of the transport sector is made by forecasting growth of consumption of the mechanical energy first, and converting the obtained mechanical energy in the year 2050 to the primary energy demand using efficiencies of energy conversion of the chosen transport technologies (i.e. internal combustion engines using biofuel or biogas and electric cars) afterwards. The electricity consumption shown in Table II is the so- called "fixed" or "inelastic" electricity consumption which is included in the model with the hourly distribution profile corresponding to the actual Latvian electricity load distribution during the year 2008. In addition, the model allows permits the calculation of the so-called "flexible" electricity consumption and these are the consumers (i.e. electric transportation with batteries and hydrogen fuel cell vehicles) which could adjust the power demand within time period from 1 day to 4 weeks. It should be noted that the size of the population in Latvia is predicted to be around 1,8 million in the year 2050 [11] which means that specific electricity consumption would be around 6,7 $\mathrm{MWh} /$ capita, which is more than 2 times greater than in the year 2007 which would be close to the average per capita consumption of electricity in EU-27 countries during 2007 [4].

The amount of district heating energy consumption and consumption of primary energy in household and industry sectors, which is used mostly for heat production, for the year
2050 shown in the Table II are not forecasted data but obtained by modeling the energy demand and supply situation for the year 2050. Namely, the modeling allowed to conclude that the development of a $100 \%$ self-sufficient energy system within limits of biomass, biogas and waste potential (Table I) is possible on the conditions that:

- district heating energy consumption does not exceed approximately $4 \mathrm{TWh}$ /year,

- the demand of primary energy for heat production in the end-use sector does not exceed about $12 \mathrm{TWh}$;

- "flexible" electricity consumption of the transport sector does not exceed approximately $4 \mathrm{TWh} /$ year if the "fixed" electricity consumption is $12 \mathrm{TWh} /$ year and the total demand of mechanical energy for the transportation is $8,8 \mathrm{TWh} /$ year.

The assumption that district heating consumption and the demand of primary energy for heat production in the end-use sector by more than $30 \%$ (nearly $50 \%$ in the household sector) compared to the demand in the year 2020 is based on the consideration of energy efficiency measures in the building sector which should be implemented to a considerable extent by the year 2050. The reduction of the heat demand allows allocating more biomass resources, previously used for heat production, to the transport sector for the production of biofuel. It is reasonable to assume that a considerable reduction of energy use for heating needs is more feasible during the studied time period than the reduction of energy use for transportation and electricity supply.

The modeling of a $100 \%$ self-sufficient energy system was done by creating two scenarios: ,wind scenario" and ,solar scenario" and both scenarios satisfy the energy demand shown in Table II for the year 2050. In the „wind scenario" the energy demand of the transport sector is provided, to a large extent due to the increased capacities of wind power plants, and these capacities considerably exceed the estimated potential provided in Table I.

The main characteristic values of the "wind scenario" are the following:

1. total gross national electricity consumption is nearly 16 TWh, from which the "fixed" consumption is 12 TWh (Table I), consumption of the "flexible" consumers, i.e. electrical transport is equal to $3,8 \mathrm{TWh} / y e a r$, and consumption by heat pumps in the district heating systems with cogeneration plants is equal to $0,06 \mathrm{TWh}$;

2. installed capacity of onshore wind power stations reaches $1000 \mathrm{MW}_{\mathrm{e}}$ (with annual electricity production of 2,2 TWh), installed capacity of offshore wind power stations is equal to $1600 \mathrm{MW}_{\mathrm{e}}$ (with annual electricity production of $4 \mathrm{TWh}$ ) (Fig. 1,2);

3. installed capacity of large hydro power plants is 1535 MWe and that of the small river hydro power plants 39 MWe (which is basically the current situation), and hydropower plants produce 2,8 TWh/year (Fig. 1,2);

4. total installed electric capacity of biomass CHP plants is $300 \mathrm{MWe}$ (power-to-heat ratio is 0,5 ), and $182 \mathrm{MWe}$ is available for operation in the condensing mode. 1,5 TWh of electricity plus 3,1 TWh of district heat are produced by CHP plants (Fig. 2); 
5. total installed electric capacity of biogas-fired combined cycle power plant is $1200 \mathrm{MW}_{\mathrm{e}}$, and the biogas consumption for production of $3,8 \mathrm{TWh}$ of electricity is about $7 \mathrm{TWh} /$ year (Fig. 1,2). ;

6. 0,6 TWh of electricity is produced by waste-to-energy plants consuming 1,8 TWh/year of waste (Fig. 1, 2);

7. about $0,6 \mathrm{TWh} /$ year of electricity is exported since the electricity system is unable to consume all the surplus power produced by the peak production of wind power plants, mostly in time periods from December to February;

8. biomass consumption in end-use sectors which exclude household and transport sectors is 8,5 TWh/year;

9. total heat energy consumption in the household sector which is supplied from individual heating sources is 3,1 $\mathrm{TWh} /$ year, where 2,8 TWh of heat energy is covered with solar energy and 0,3 TWh - with biomass produced energy (at biomass conversion efficiency of $0,85)$

10. approximately $0,6 \mathrm{TWh}$ of district heating is produced by solar thermal collectors, $0,2 \mathrm{TWh}$ are produced by heat pumps (COP value of 3 is used in the calculations) and the rest is produced by biomass-fired CHPs and boiler plants;

11. total biomass consumption for electricity and heat production is equal to approximately $18 \mathrm{TWh} / \mathrm{year}$, and about 12 TWh of biomass is used in the transport sector (Table III, Fig. 1).

Figure 1 shows the mix of primary energy resources and electricity which covers the energy demand for electricity production, heat supply and transportation needs in the "wind scenario".

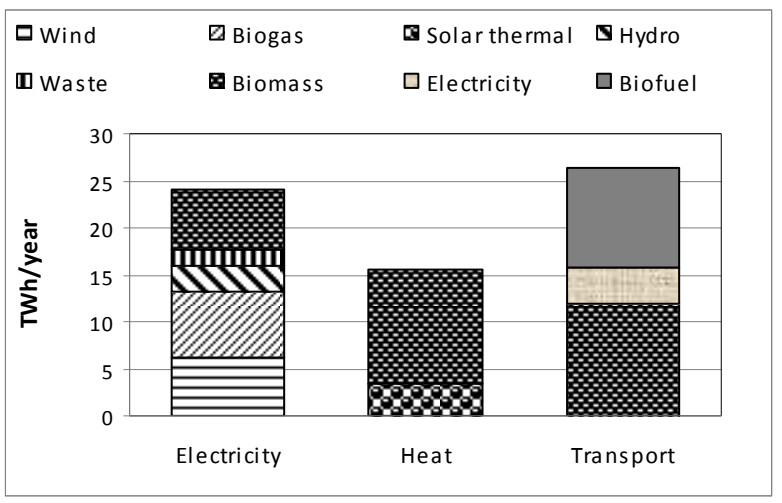

Fig. 1. Consumption of primary energy resources and electricity for supply of electricity, heating and coverage of transportation demand in the ,wind scenario".

As it is shown in Figure 1, the largest share of primary resource consumption in electricity production is taken by biogas used in combined cycle power plant, followed by biomass used in cogeneration plants and wind energy with nearly equal volumes. Biomass in both scenarios is allocated between electricity and heat production in CHP plants corresponding to the amounts of produced electricity and heat. This allocation is justified by the assumption that CHP plants use condensing heat exchangers for flue gas cooling and total fuel efficiency of CHP plants, based on the lower heating value of fuel and used in calculations, is $100 \%$.

Biogas in the considered scenarios is used in the combined cycle condensing power plant providing a base load for the power system since this might be the most feasible solution for securing the electricity base load. It is assumed in the calculations that $30 \%$ of the total electricity production must come from grid-stabilising units, i.e. biogas combined cycle power plant. Additionally, since it is presumed in the modeling of the future scenario that the consumption of district heat will decrease, the heat load available for cogeneration will decrease as well and therefore a role of the biomass cogeneration in the power production will diminish. Use of biogas in large base-load power plants would require developing technologies which allow the feed-in of biogas into the existing infrastructure of the natural gas supply.

Biomass and solar thermal energy are two main resources for heat production (Fig. 1). Heat energy in the district heating systems which have cogeneration plants is supplied mainly by biomass but, in the district heating systems with no cogeneration plants and the household sector, heat energy is supplied mainly from solar collector systems. The use of solar collector systems saves more biomass for cogeneration plants and the transport sector. It is assumed in the calculations that heat storage facilities are used in combination with solar collector systems both in district heating systems and the household sector in order to increase the possibilities for the utilisation of solar energy.

The share of district heating produced by the heat pumps is very small in both scenarios $(4,5 \%)$, and the heat pumps are used only in the district heating systems in combination with CHP plants and heat accumulators in order to utilise electricity produced by wind power plants during the hours of surplus electricity production for heat production. Biomass used for biofuel production has the largest share in primary energy consumption also in the transport sector as well (Fig. 1).

Energy consumption of transport sector is covered by three types of energy resources - biofuel derived from woody biomass (the term "biomass" is used in figures for the transport sector) which is not consumed in the district heating systems and end-user sector for the heat production, biofuel derived from energy crops (Table I) and electricity.

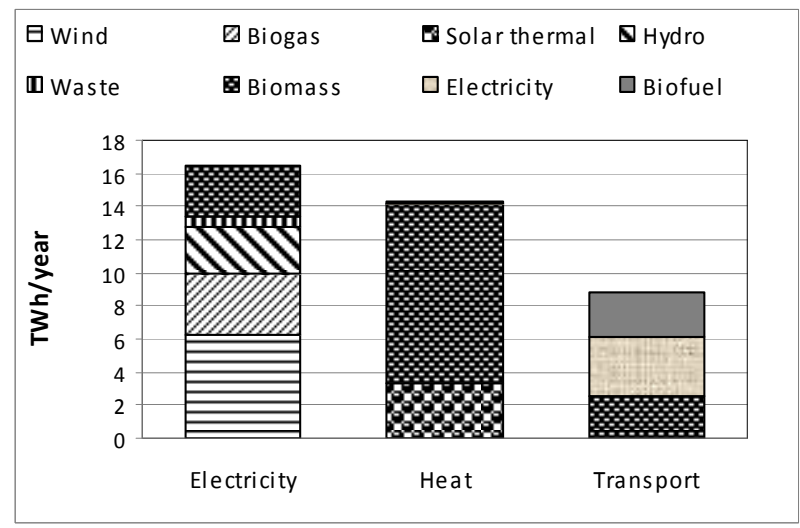

Fig. 2. Secondary energy consumption by the energy resources used for coverage of the secondary energy demand (mechanical energy is shown for the transport sector) in the ,wind scenario". 
The total primary energy consumption in the "wind scenario" is nearly 66 TWh/year which exceeds the consumption in the year 2008 by $21 \%$.

When the secondary energy is analysed by the sources of origin (Fig. 2), then it is clearly seen that wind energy is the dominant source for electricity production in the "wind scenario". Biogas is the second most important source followed by biomass and hydro energy but the role of waste energy for power production is considerably lower. This is a distinct picture from the existing situation where hydropower plants produce from over 30 to nearly $50 \%$ from gross national electricity consumption (depending on the availability of water flow), shares of wind and biomass is practically negligible and waste not being used at all.

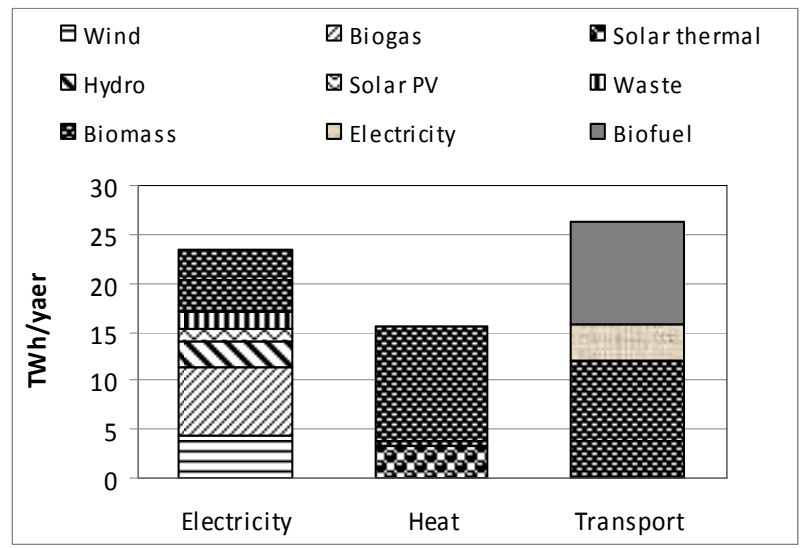

Fig. 3. Consumption of primary energy resources and electricity for supply of electricity, heating and coverage of transportation demand in the ,solar scenario".

Approximately $75 \%$ of all heating needs are covered by using biomass (Fig. 2) and solar thermal energy is used for supply of almost all of the remaining heat demand (the share of electricity used in heat pumps is only about $1 \%$ ).

Electricity is the single most important source of motive power in transportation (Fig. 2, Table III) and mechanical energy produced from electricity has a share of over $40 \%$. Electricity in the transport sector is provided primarily by wind power plants utilizing possibilities of "flexible" demand for transport as already described previously. Biofuel produced from woody biomass and energy crops cover the remaining $60 \%$ of the transport energy demand (Fig. 2, Table III).

TABLE III

COVERAGE OF MECHANICAL ENERGY IN TRANSPORT SECTOR

\begin{tabular}{|l|l|l|}
\hline $\begin{array}{l}\text { Type of energy } \\
\text { source }\end{array}$ & $\begin{array}{l}\text { Primary energy, } \\
\text { TWh/year }\end{array}$ & $\begin{array}{l}\text { Mechanical energy, } \\
\text { TWh/year }\end{array}$ \\
\hline Electricity & 3,8 & 3,6 \\
\hline Biofuel & 10,5 & 2,7 \\
\hline Biomass & 12 & 2,5 \\
\hline
\end{tabular}

In the above described "wind scenario", the capacities of wind power plants exceed the maximum capacities defined as the wind power capacity potential for Latvia shown in Table I (which may change in the future along with other figures of the domestic resource potential shown in Table I). For this reason, the scenario in which the electricity for "flexible" electric transportation would be covered partly by solar PV technologies, and the capacity of wind power plants would correspond to the estimated potential indicated in Table I was created and named as the "solar scenario". Thus, part of the wind power plant capacity is substituted by the solar PV capacity (Fig. 3, 4).

The main characteristics of the ,solar scenario" which differ from the "wind scenario" are the following:

- installed capacity of onshore wind power stations is 600 $\mathrm{MW}_{\mathrm{e}}$ (with annual electricity production of 1,3 $\mathrm{TWh}$ ); installed capacity of offshore wind power stations is equal to $1200 \mathrm{MW}_{\mathrm{e}}$ (with annual electricity production of 3 TWh) (Fig. 3, 4);

- total installed capacity of solar PV plants is $1550 \mathrm{MW}_{\mathrm{e}}$ and 1,3 TWh of electricity is produced yearly by these plants (Fig. 3, 4);

- amount of power export is negligible since production of surplus electricity is practically avoided in this scenario.

The mix of resources used for the heat supply and transport sectors remain the same as in the "wind scenario" (Fig. 4).

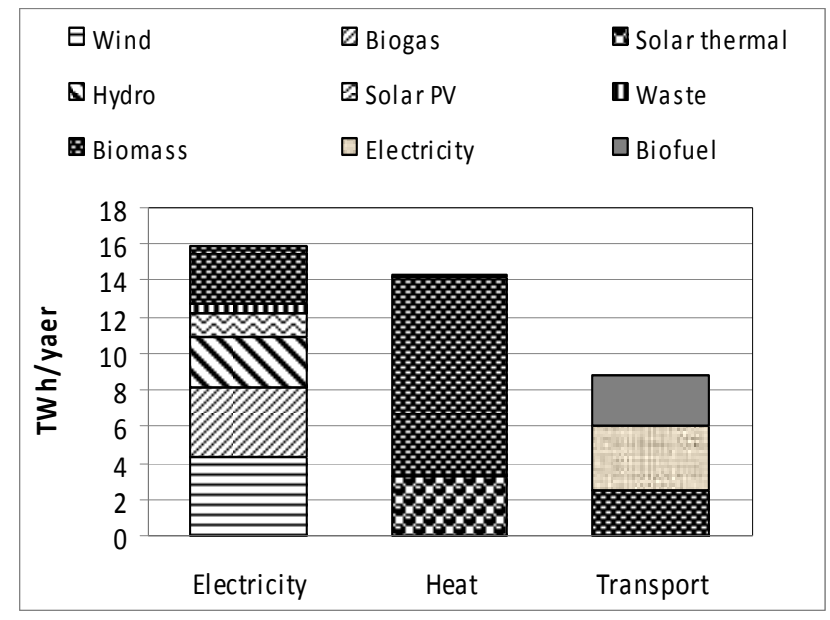

Fig. 4. Secondary energy consumption by the energy resources used for coverage of the secondary energy demand (mechanical energy is shown for the transport sector) in the ,solar scenario".

The total installed capacity of solar PV plants of 1550 $\mathrm{MW}_{\mathrm{e}}$, which was needed in order to match power demand and supply in the "solar scenario" when the constraints of potential of other resources are considered (Table I), is close to the installed solar PV capacity in the $100 \%$ renewable energy system plan for the Denmark for the year 2050 [12]. However, $1000 \mathrm{MW}$ of wave power capacity was used in the plan for Denmark [12] which was not used in this study at all.

The total primary energy consumption in the "solar scenario" is approximately $65 \mathrm{TWh} /$ year which is a little bit less than in the "wind scenario" since slightly less electricity is produced and no power is exported. Thus, the total primary energy consumption in the "solar scenario" exceeds the consumption in the year 2008 by $19 \%$.

As was mentioned above, the energy demand and supply was modeled by "EnergyPLAN" on an hourly basis and the results of calculations for the first week of January in 
electricity and district heating systems of the "solar scenario" are shown in Figures 5 to 8. As can be seen from Figures 5, 6 and 8, CHP plants operate in base-load (Fig. 6, 8) during winter time and electric transport as a "flexible" consumer and heat pumps use electricity produced by fluctuating renewable sources (mostly wind power) during periods when the power supply exceeds the "fixed" electricity demand (Fig. 5). As was mentioned before, amounts of electricity import and export are negligible in the "solar scenario" and that can be seen from Figures 5 and 6.

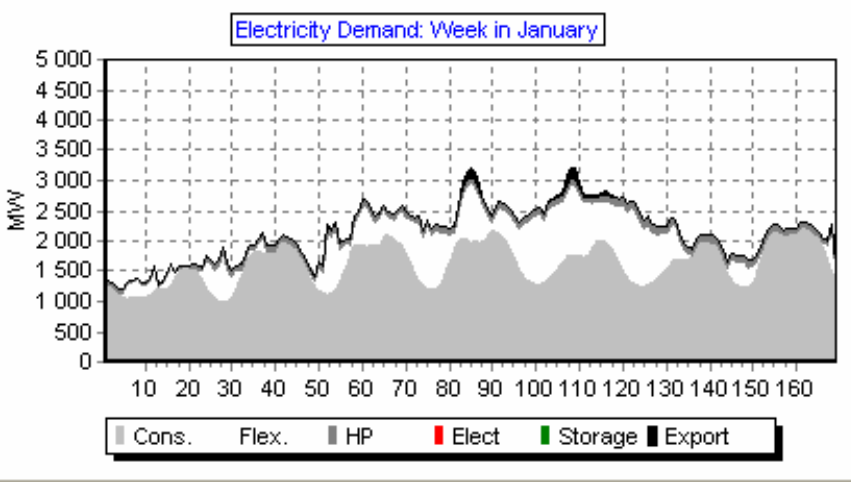

Fig. 5. Electricity demand during the first week of January (Cons.-"fixed" electricity consumption; Flex.-flexible electricity consumption; HP-heat pump electricity consumption; Elect.-electricity consumption needed for electrolysis; Storage-electricity storage; Export - electricity export).

The average electric capacity of large hydropower plants is $220 \mathrm{MW}_{\mathrm{e}}$, circa $970 \mathrm{MW}_{\mathrm{e}}$ are provided by wind, solar and small hydropower plants altogether, $554 \mathrm{MW}_{\mathrm{e}}$ is the average capacity of biogas combined cycle plant, $284 \mathrm{MW}_{\mathrm{e}}$ are secured by CHPs and the remaining $67 \mathrm{MW}_{\mathrm{e}}$ are supplied by waste-to-energy plant on average during January. When considering the whole year, the maximum electric load of the "fixed" electricity consumers is around $2230 \mathrm{MW}_{\mathrm{e}}$, and the minimum is close to $650 \mathrm{MW}_{\mathrm{e}}$.

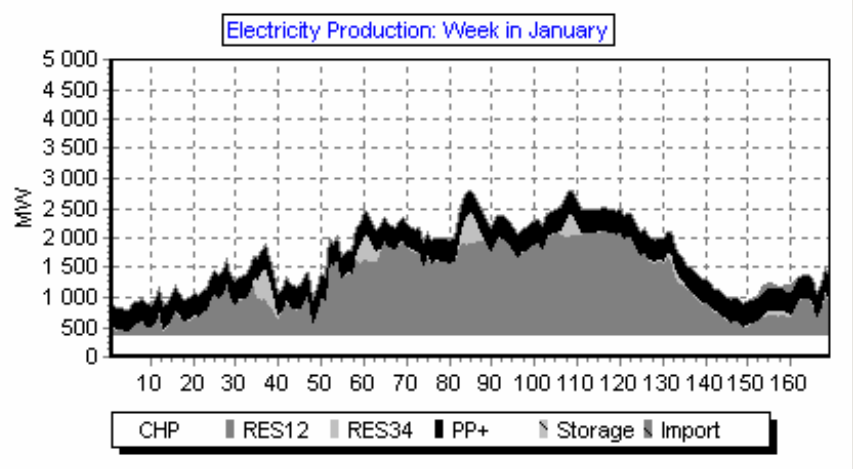

Fig. 6. Electricity production during the first week of January (CHPcogeneration; RES12-on-shore and offshore wind power plants; RES34-solar PV and small hydropower plants; PP+-large hydropower plants and condensing power plants as well as condensing tail of CHP plants; Storageelectricity production from storage and V2G transportation; Import-electricity import).

As shown in Figure 7, the district heating demand is divided among 3 groups, representing district heating systems with no CHP plants, district heating systems with distributed small
CHP generation and large district heating systems with large CHP plants which are also able to operate in condensing mode. The district heating production for supply of these groups is $0,7,1,3$ and 2,0 TWh, respectively (Fig. 7) summing up to $4 \mathrm{TWh}$ of the total production as was mentioned before. The maximum total heat load of the district heating system is close to $1540 \mathrm{MW}_{\mathrm{t}}$, and the minimum is $140 \mathrm{MW}_{\mathrm{t}}$ if the whole year is considered. The average heat capacity of CHP plants in January is nearly $580 \mathrm{MW}_{\mathrm{t}}$, heat pumps provide close to 100 $\mathrm{MW}_{\mathrm{t}}$ on average, solar thermal average capacity is around 80 $\mathrm{MW}_{\mathrm{t}}$ but boilers supply $105 \mathrm{MW}_{\mathrm{t}}$ on average to cover heat peak loads of "no-CHP" (Group 1) district heating systems with solar thermal collectors and CHP plants in district heating system Groups 2 and 3 during January.

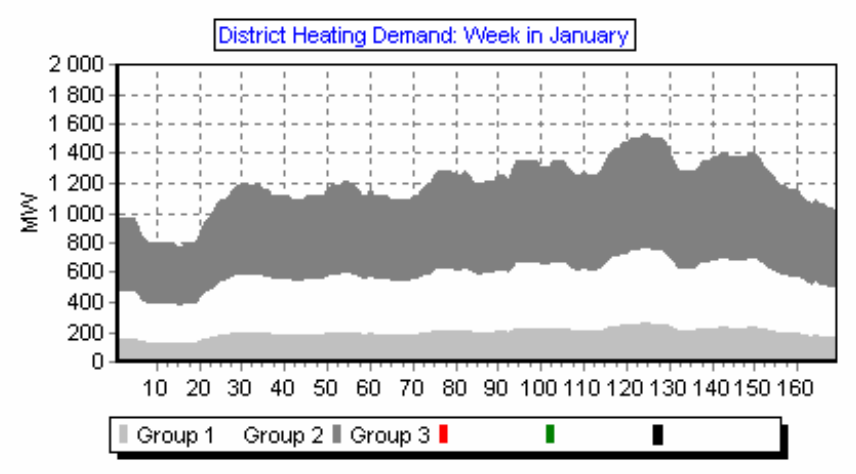

Fig. 7. District heating demand during the first week of January (Group 1district heating (DH) systems without CHP; Group 2-DH systems with relatively small, i.e. distributed CHP's; Group 3-DH systems with large CHP's, i.e. extraction steam turbine plants).

It should be noted that "EnergyPLAN" allows to choose different energy system regulation strategies for modeling [1], and a strategy in which all heat supply sources are producing solely according to the heat demand was chosen for the simulations presented in this paper. The priority in "dispatch" of heat is given to solar thermal units, followed by CHP and heat pumps with peak load boilers dispatched the last (Fig. 8). Figures 5 and 8 demonstrate that heat pumps are used in time periods of large wind production when surplus electricity is generated.

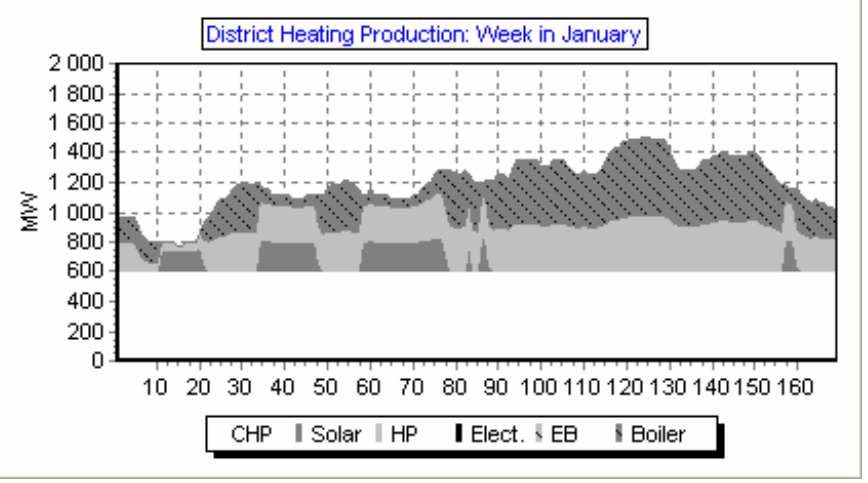

Fig. 8. District heating production during the first week of January (CHPcogeneration; Solar-solar thermal collectors; HP-heat pumps; Elect.-heat from electrolysis equipment; EB-electric heating; Boiler-water heating boilers). 
Researchers at Aalborg University in Denmark and the Danish Society of Engineers clearly showed that it is possible to develop model of energy system that is able to completely cover energy demand by the means of renewable energy resources only [12]. The research in Denmark was based on studies of potentials of available resources, and assumptions that energy efficiency measures will be performed in district heating sector, energy end-use sectors including industry and transport, which will allow to reduce primary energy requirement of the country by more than two times compared to the reference or "business-as-usual" scenario for the year 2030 [12]. By using the same modeling program "EnergyPLAN" it is shown that it is possible to develop 100\% renewable energy system for Latvia as well. However, the Latvian 100\% renewable energy plan (the scenarios presented in this paper) is based on the assumption that the primary energy demand will be greater than the existing demand (for the year 2008) by approximately $20 \%$ since in spite of decreasing energy demand for heating purposes, electricity consumption and the needs of energy sources for transport will grow. This is a reasonable assumption considering the necessity for substantial development of the Latvian economy. Similarly to the Danish plan, biomass is the main energy source followed by wind. However, hydropower plants are a substantial source of electricity in Latvia which is not the case in the plan for Denmark. The opposite can be said about wave power as already mentioned above, since the wave power capacity was not included in the Latvian energy plan but it is substantial in the Danish plan. Solar thermal and solar PV energy are important renewable energy sources in both plans. It should also be noted that the share of electricity in the energy demand which is summed up by electricity and heat demand as well as primary energy and electricity demand for transportation (the sum will be called EHT energy demand here for simplicity) is nearly the same for the Danish and Latvian plans, i.e. around $29 \%$. But the shares of heat demand and transport demand in EHT energy demand in the Danish plan is approximately $42 \%$ and $29 \%$, respectively [12] while in the Latvian plan the share of the transport is around $46 \%$ while the share of the heat demand is $25 \%$. The share of electricity in the energy consumption for transportation is circa $17 \%$ in the Danish plan (not including electricity used for hydrogen production for fuel cell vehicles) [12] and about $14 \%$ in the Latvian plan. No hydrogen electrolysis is modeled in the Latvian plan in distinction to the Danish plan.

Finland, similarly to Denmark, has developed possible energy sector development plan in order for the sector to become $\mathrm{CO}_{2}$-neutral by the year 2050. The forecast for changes in heat energy and power use in Finland according to the tendencies of state development and comparison with the Latvian $100 \%$ renewable energy plan presented in this paper are the following [13]:

1. gross heat energy consumption will decrease by $32 \%$ in comparison with the year 2009 , which is similar to the assumption in the Latvian energy plan;

2. proportion of district heating will increase from $44 \%$ to $52 \%$ which is opposite to the Latvian energy plan where it is assumed that the share of district heating in the total heat production will decrease from around $37 \%$ (in the year 2007) to $28 \%$ since energy efficiency improvements during the studied time period shall reduce heat consumption in the district heating systems substantially;

3. use of electrical energy for heating needs will increase from $18 \%$ to $20 \%$ (very little electricity is planned to be used for heating in the Latvian case as already mentioned previously);

4. total increase of power consumption for the year 2050 relative to the year 2007 in Finnish development plan is within the range of $26-53 \%$ [13]. It should be noted that in the presented Latvian energy plan the assumed increase of gross national power consumption is $54 \%$ (Table II);

5. energy consumption of transport (excluding the electric transportation) will increase by $40 \%$ by the year 2050 in comparison with the year 2006. Calculations of this study are based on the forecasted increase of mechanical energy needs for transportation by more than two times (Table II).

The following solutions are proposed in the energy plan for Finland in order to cover consumption growth and are to assure that the energy sector is $\mathrm{CO}_{2}$-neutral [13]:

1. $\mathrm{CO}_{2}$ capture and storage - implemented in boiler houses and large-scale thermal power stations providing that applied technologies are efficient;

2. development of multi-fuel plants where wood is used as the main type of fuel;

3. construction of new biomass plants and renovation of the old plants;

4. increase of hydropower station use;

5. increase of amount of electricity produced by wind power by $10-15 \%$.

When comparing the plans of Finland and Latvia, it can be noted that biomass, hydropower and wind plays an important role in the Latvian plan as well, but the main difference is that the Latvian plan is a $100 \%$ renewable energy plan and $\mathrm{CO}_{2}$ sequestration is not planned.

\section{CONCLUSIONS}

The presented study shows that it could be possible to develop an energy supply system (results of the "solar scenario" are presented in the conclusions) which is $100 \%$ based on the renewable energy sources even within the limits of the potential of those resources estimated with existing knowledge. However, the scenario with complete energy selfsufficiency can be achieved with the known potential of domestic resources if the increase of the total primary energy demand during the time period up to 2050 stays within approximately $20 \%$ relative to the demand in 2008 , i.e. not exceeding the value of circa $65 \mathrm{TWh} /$ year. That could require that the energy intensity of GDP in 2050 would have to be only $50 \%$ of the energy intensity of the Latvian economy in the year 2007 (based on the assumptions that GDP, calculated in prices of the year 2000, in 2050 will be approximately 2,4 times greater than in 2008) which would correspond to the 
average energy intensity of OECD countries in the year 2007 [4]. It was assumed in the studies that the largest potential for energy efficiency improvements can be found in the heat supply sector which will demonstrate a decrease of the energy demand opposite to electricity supply and transport sectors.

Biomass resources with over 30 TWh of annual consumption would play a major role in the energy supply providing energy for electricity and heat production, as well as for transportation via biomass-to-liquid biofuel conversion processes. Biomass will be the main energy source for heat production but wind power $\left(1,8 \mathrm{GW}_{\mathrm{e}}\right)$ followed by biogas (7 TWh of primary energy) will be more important energy sources for electricity production than the biomass. Hydropower plants $\left(1,57 \mathrm{GWh}_{\mathrm{e}} ; 2,8 \mathrm{TWh} /\right.$ year $)$ will remain as thefourth main source for power production. Solar PV $(1,55$ $\left.\mathrm{GW}_{\mathrm{e}}\right)$ and waste-to-energy plants $(1,8 \mathrm{TWh} /$ year of primary energy) would produce the remaining amount of electricity, the solar PV plants providing twice as much electricity as the waste incineration plants. Important finding is that biogasfired power plant could be the most feasible source of power base-load and that would call for development of infrastructure and technical systems which could use the existing system of natural gas supply for collection and supply of the biogas to the large base-load power plants.

A wider application of solar collectors for securing heat energy demand in district heating and individual heating systems in order to save more biomass for biofuel production has to be promoted to a considerable extent $(3,4 \mathrm{TWh} / \mathrm{year})$. The necessity to rely substantially on solar energy systems, both solar thermal and solar PV, is the reason for active research and development for application of these sources in the Latvian energy sector.

The study shows that the energy needs of transportation can be covered with domestic resources only if the possibilities of flexible consumption electric vehicles utilising intermittent wind and solar PV power production can be integrated in the energy system. Electricity would be the main single source of motive power in the transportation providing more than $40 \%$ and adding about $3,8 \mathrm{TWh}$ of electricity consumption to 12 TWh of the "fixed" power consumption per year, but biofuel derived from woody biomass and energy crops (with roughly equal shares) will have to be used for the transportation where electricity is not a feasible solution.

Finally, it is important to mark that if the $100 \%$ selfsufficient energy scenario which correspond to the "solar scenario" of this study would have to be implemented, the renewable energy solutions which would have to play a very important role in Latvian energy system in the long run are not the ones which are economically most feasible in the short run. Namely, electricity production from biogas, wind power and solar PV technologies are economically less attractive now than using biomass CHP's. But as can be seen from the presented study, the role of biomass CHP's will diminish as heat loads will decrease and biogas, wind and solar technologies would have to become increasingly more significant sources of energy supply. Energy policy has to consider this disagreement between short and long run optimal renewable energy solutions in order to provide timely opportunities for development and introduction of the long run solutions if additional support will be required.

\section{REFERENCES}

1. EnergyPLAN - Advanced Energy System Analysis Computer Model (hosted by Aalborg University, Denmark), Available: http://www.energyPLAN.eu.

2. Connolly D et al. „A review of computer tools for analysing the integration of renewable energy into various energy systems." - Appl. Energy (2009), doi:10.1016/j.apenergy.2009.09.026.

3. Lund H. „EnergyPLAN. Advanced Energy Systems Analysis Computer Model" - Documentation Version 7.2, Aalborg University, Denmark. 2009 - 117 pages.

4. Ministry of Economics of the Republic of Latvia: „Latvian Energy in Figures”, 2009, 35 pages.

5. Lazdiņš A. „Bioenergy promotion projects (The Baltic Sea Region Bioenergy Promotion Project)", Vides projekti, 2009.

6. Dzene I. „Atjaunojamo energoresursu palielināšanas potenciāla analīze“, RTU VASSI, Vides Ministrija - 01.07.2009.

7. Dubrovskis V.: Biogas in Latvia. Proc. International workshop Biogas in Change 2.02.2007., Congress Center, Leipzig.

8. Berzina A. „Analysis ecodesign inflammation and solution by using systemdynamic modeling” - Riga, 2010.

9. Deniņa A., ,Atjaunojamie energoresursi Latvijā - status quo, potenciāls un iespējas" $\quad-\quad 12 . \quad 1 p p$ http://www.rms.lv/bionett/Files/Latvija_ES_zurnals_3_18_40_lpp\%5B 1\%5D.pdf - [Accessed 21.04.2010].

10. Report of research project- ASSESSMENT ON THE USE OF RENEWABLE ENERGY RESOURCES IN LATVIA UNTIL 2020, Riga Technical University, Faculty of Energy and Electrical Engineering, Institute of Energy Systems and Environment; Riga, August-December, 2008, 130 pages.

11. Zvidriņš P., Krūmiņš J., Leduskrasta Z. u.c. „Demogrāfiskā situācija šodien un rīt", "Pērse", 2005.g.

12. Lund H., Mathiesen B.V. „Energy system analysis of $100 \%$ renewable energy systems - The case of Denmark in years 2030 and 2050" Energy 34 (2009) p. 524-531.

13. Ramo K., Naukkarinen J. „Turning challenges into opportunities - a carbon neutral vision for electricity and district heat for 2050". Finnish Energy Industries, Lappeenranta University of Technology, Tampere University of Technology, Turku School of Economics, Finland Futures Research Centre, 2009 - 40 pages.

Jekaterina Porubova, Mr. Sc, PhD student

Institute of Energy Systems and Environment, Riga Technical University

Address: Kronvalda boulv. 1, LV-1010, Riga, Latvia

Phone: +371 67089911, Fax: +37167089908

e-mail: kesja_1@inbox.lv

Gatis Bazbauers, Dr.sc.ing., Professor

Institute of Energy Systems and Environment, Riga Technical University

Address: Kronvalda boulv. 1, LV-1010, Riga, Latvia

Phone: +371 67089911, Fax: +37167089908

e-mail: gatis.bazbauers@ @rtu.lv

Jekaterina Porubova, Gatis Bažbauers. Ilgtermiṇa energoapgādes sistēmas plāna analīze Latvijai, kas balstītos uz 100\% vietējo energoresursu izmantošanu

Arvien lielāka uzmanība pasaulē tiek pievērsta globālajām klimata pārmainām, ko veicina fosilo kurināmo izmantošana. No otras puses, ir vērojams nemitīgs enerǵijas pieprasījuma pieaugums, kas ierobežota fosilā kurināmā daudzuma apstākḷıs noved pie saražotās enerğijas izmaksu palielināšanās. Pastāv reǵioni un valstis, kuru energoapgādes sistēmas ir būtiski atkarīgas no energoresursu importa un Latvijas valsts ir pieskaitāma pie tādām. Ja energoapgādes sistēma lielā mērā balstās uz kurināma importu, tad valsts nevar būt pārliecināta par piegāžu drošumu, ko var ietekmēt gan politiskie, gan ekonomiskie apstākḷi. Ievērojot nepieciešamību mazināt energoapgādes ietekmi uz vidi un palielināt drošību, arvien vairāk pilsētu, valsts reǵionu un valsts apgabalu mēǵina veidot 
energoapgādes sistēmu plānus un sistēmas, kas balstās uz vietējo energoresursu izmantošanu, bet retāk tādi plāni tiek izstrādāti valsts līmenī. Tāpat tiek izstrādāti rīcības plāni, kas paredz risinājumus, lai energoapgādes sistēmas attīstītu līdz pilnībā $\mathrm{CO}_{2}$ neitrālam stāvoklim.

Pāreja no fosilās enerǵētikas uz energoapgādes sistēmu, kas balstās uz vietējiem energoresursiem, nozīmē, ka energosistēmai mainīsies struktūra un darbības princips, jo tikai biomasas un hidroresursu enerğijas avotiem ir iespējams prognozēt un vadīt enerğijas izstrādi. Taču pārējiem atjaunojamiem energoresursiem, tādiem kā vēja un saules enerğijai, ir l̦oti mainīgs pieejamības raksturs, un līdz ar to ir jāmeklē risinājumi šo energoavotu izstrādātās enerǵijas uzkrāšanai.

Darbā ir atspoguḷoti divi Latvijas energoapgādes sistēmas attīstības scenāriji, kas spēj pilnībā nodrošināt energoapgādes sistēmas patēriṇu, balstoties uz vietējiem energoresursiem. Scenāriji ir izveidoti ar Dānijā, Ālborgas universitātē izstrādāto energoapgādes sistēmas analīzes un modelēšanas programmu „EnergyPlan”, kura tika izmantota līdzīga plāna izveidei Dānijas apstākḷiem. Galvenā atšksirība starp darbā parādītajiem scenārijiem ir vēja un saules foto-galvanisko elektrostaciju īpatsvars elektroenerğijas izstrādē.

Darbā tika aplūkoti Dānijas un Somijas piemēri 100\% uz atjaunojamiem energoresursiem balstītu un $\mathrm{CO}_{2}$ neitrālu energoapgādes sistēmu modelēšanā, tos salīdzinot ar Latvijai izstrādātajiem scenārijiem

Екатерина Порубова, Гатис Бажбауэрс. Анализ долгосрочного плана системы энергоснабжения Латвии, который на $100 \%$ основывается на использовании местных энергоресурсов

Все большее внимание в мире обращают на глобальное изменение климата, которому способствует использование ископаемого топлива. С другой стороны, происходит непрерывный рост потребления энергии, который в условиях ограниченного количества ископаемого топлива способствует увеличению расходов на производимую энергию. Существуют регионы, система энергоснабжения которых существенно зависит от импорта энергоресурсов, и Латвия относится к таковым. Если система энергоснабжения опирается на импорт топлива, то государство не может быть уверено в стабильности поставок, как из-за политических, так и из-за экономических условий. В связи с этим, все больше и больше городов, государственных регионов пытаются создать системы энергоснабжения, которые основываются на использовании местных энергоресурсов. Реже подобного рода планы разрабатываются на государственном уровне. Также разрабатываются планы действия, которые предполагают, что системы энергоснабжения станут $\mathrm{CO}_{2}$ нейтральными.

Переход ископаемой энергетики на энергетику, опирающуюся на местные энергоресурсы, означает, что у системы энергоснабжения изменится структура и принцип работы, потому что только при использовании биомассы и гидроресурсов возможно прогнозировать и управлять выработку энергии. У остальных местных ресурсов, таких как ветер и солнце, очень переменчивый характер для выработки энергии, поэтому необходимо искать решения для накапливания энергии.

В работе рассматриваются два сценария развития системы энергоснабжения Латвии, которые способны полностью обеспечить энергопотребление. Сценарии развития созданы, используя программу „ЕnergyPlan”, которая была разработана в Дании, Альборгском университете для моделирования и анализа систем энергоснабжения. „EnergyPlan” так же использовалась в разработке похожих сценариев для Датских условий. Главные различия между сценариями, отображенными в работе, является доля ветровых и солнечных фотогальванических электростанций в выработке электроэнергии. В работе рассматриваются примеры моделирования $\mathrm{CO}_{2}$ нейтральных систем энергоснабжения и систем энергоснабжения, которые $100 \%$ основываются на возобновляемые энергоресурсы, таких стран как Дания и Финляндия, а так же сравнивается их опыт со сценариями разработанными для Латвии. 